\title{
The Hobo Anomalous: class, minorities and political invention in the Industrial Workers of the World
}

\author{
Nicholas Thoburn \\ Department of Sociology, Goldsmiths College, University of London, \\ New Cross, London SE14 6NW, UK
}

\begin{abstract}
This article is an analysis of minority political invention in the Industrial Workers of the World (IWW). Against the tendency in recent social and cultural theory to dichotomize class and difference, it argues that it was in and through the IWW's formulation of class that minority political and cultural invention occurred. Using the framework of Deleuze and Guattari's minor politics, the article shows how the IWW's composition in the simultaneously diffuse and cramped plane of work operated against the major political identities and subjects of worker, immigrant, American, citizen and 'people', and towards the creation of minority political knowledges, tactics and cultural styles premised on the condition that 'the people are missing'. Seeking to understand the IWW's modes and techniques of invention, the article explores the general plane of IWW composition, its particular political and cultural expressions (in songs, manifestos, cartoons and tactics), and its minor mode of authorship. The article focuses in particular on two aspects of IWW minority composition, the itinerant worker, or hobo, and the politics of sabotage.
\end{abstract}

Keywords: Class, hobo, Industrial Workers of the World, minor politics, sabotage.

Shall we still be slaves and work for wages?

It is outrageous—has been for ages. ('Workingmen, Unite!', IWW 1989: 64)

The wobbly movement has never been more than a radical fungus on the labor movement. Those who could not fit in to a normal, rational movement. (Samuel Gompers, President of the AFL, cited in The Wobblies 1979)

To an assembly of nearly 200 assorted unionists, revolutionaries, socialists and anarchists from thirty-four state, district, and national organizations, William D. Haywood opened the founding convention of the Industrial Workers of the World (IWW) in Chicago, 27 
June 1905, with the words 'Fellow Workers. This is the Continental Congress of the Working Class' (cited in Kornbluh 1998: 1). In almost mathematical simplicity the Preamble to the Constitution, reiterated in every IWW publication, elaborates the contours of this 'working class' a little further:

The working class and the employing class have nothing in common. There can be no peace so long as hunger and want are found among millions of the working people and the few, who make up the employing class, have all the good things of life.

Between these two classes a struggle must go on until the workers of the world organize as a class, take possession of the earth and the machinery of production, and abolish the wage system.

We find that the centering of the management of industries into fewer and fewer hands makes the trade unions unable to cope with the ever-growing power of the employing class. The trade unions foster a state of affairs which allows one set of workers to be pitted against another set of workers in the same industry, thereby helping defeat one another in wage wars. Moreover, the trade unions aid the employing class to mislead the workers into the belief that the working class have interests in common with their employers.

These conditions can be changed and the interests of the working class upheld only by an organization formed in such a way that all its members in any one industry, or in all industries if necessary, cease work whenever a strike or lockout is on in any department thereof, thus making an injury to one an injury to all.

Instead of the conservative motto, 'A fair day's wages for a fair day's work', we must inscribe on our banner the revolutionary watchword, 'Abolition of the wage system'.

It is the historic mission of the working class to do away with capitalism. The army of production must be organized, not only for the everyday struggle with capitalists, but also to carry on production when capitalism shall have been overthrown. By organizing industrially we are forming the structure of the new society within the shell of the old. (IWW 1972: 5-6) ${ }^{1}$

It might be tempting, following the critique of class essentialism and the apparent emphasis on difference in post-Marxist and new social movement theory, to perceive this formulation as belonging to a discredited framework of the working class as universal subject with coherent identity and determined trajectory. I want, however, to make an alternative interpretation; one that does not see class and difference as mutually opposed political and methodological categories. Rather than present the IWW's 'working class' as a determined identity, this article seeks to show that it is precisely in and through the IWW's formulation of class that difference-or, more precisely, minority political invention against identity-occurs. That a certain kind of difference was registered at the time is evident in the derogatory comment of a member of the American Federation of Labor (AFL) that the founding convention was 'the greatest conglomeration of freaks that ever met in a convention' (cited in Conlin 1969: 41). But a more appropriate sign of the kinds and sources of difference with which this article is concerned can be seen in the IWW's popular name-the 'wobblies'; the origins of which evidence, if anecdotally, the IWW's polyglot composition and its close relation to itinerant labour. There are no founding declarations of this name, only two myths: that it emerged from a strike in Vancouver where a man of Chinese descent who had been feeding the strikers pro- 
nounced 'IWW', as 'I Wobble Wobble', and, though less usually proposed, that it is derived from the 'wobble' saw used by the itinerant lumberjacks (Murphy, in Bird et al. 1987: 50).

It is an abiding narrative in new social movement theory (and, arguably, the condition of the delineation of the 'new' field of politics and research) that with the development of modern capitalist societies and especially after '68, the 'working class' is seen to break down into a multiplicity of different and fragmented minority social groups. This narrative and explanatory framework tends to develop through a series of dichotomies between the 'old' class movements and the 'new' fragmented movements. Even as it seeks to overcome class analysis, this approach tends to frame the 'working class' in terms of a rather orthodox Marxist idealized representation (archetypically, the white male industrial workers of the trade union and party formations), where class is seen to signify a certain correlation between collective actors and the structures of a deep economic 'base', a degree of coherence and homogenization of styles, forms and interests, and an economic concern with the politics of property and inequality (cf. Pakulski 1993; Urry 1995). New movements are seen, in contrast, to work at a more surface level, are fragmented, mobilize apparently non-class minority concerns, are inventive in styles, tactics and goals, and are relatively less concerned with questions of economic inequality, operating more in the space of 'civil society'. To mark the clear incompatibility of the old and new political forms, Pakulski (1993: 286) argues, for example, that 'Neither the composition of the "new movements constituencies" nor the character of the publicized issues and styles of activism can be analysed in class terms.'

This article presents the problematic of the working class in a rather different fashion, and in a way that does not pose a dichotomy between class and minority concerns. It follows the sense of Balibar's (1991: 179, 170) assertion that class is not a question of identity or coherence- 'classes are not social super-individualities'-but of composition: 'there is no such thing as the "working class" solely on the basis of some more or less homogeneous sociological situation', rather, 'it exists only where there is a labour movement', or, in processes of political composition. For the wobblies, as I argue, the 'working class' was not a relatively homogeneous and demarcated social group, but a plane of composition immanent to and against the manifold social totality of capitalist relations of production; relations that were not some kind of deep and determining economic base, but the direct and everyday experience of work, in all its complexity. ${ }^{2}$ Minority formations were not an outside, or an other to the IWW's class composition, but were immanent to it; they were immanent to the exploitation of capital, and the starting point of political and cultural composition against that exploitation and its identities. As such, for the wobblies, questions of work and exploitation, and minority styles, cultural forms, and political inventions were interlaced.

In seeking to understand the IWW as class movement of minority invention against identity, this article considers the IWW through Deleuze and Guattari's (1986, 1988) methodological and political framework of 'minor politics'. Minor politics is a direct challenge to political models founded on the representation of a subject or an identity, whether in the form of a 'people' or a self-declared marginal. Against these molar models, which are premised on the fetishization of an already present identity in a nurturing social environment, minor politics operates in the 'cramped spaces', 'choked 
passages' and 'impossible' positions of 'small peoples' and 'minorities' who lack, or, manifesting a certain 'willed poverty', refuse coherent identity-those who, constrained by a wealth of determining social relations, exist under, and affirm the condition that 'the people are missing' (Deleuze and Guattari 1986: 16-17; Deleuze 1989: 216). But the minor political focus on cramped space is far from a resigned turn to the local or particular. Rather, it is a politics oriented toward social relations and their possibilities for becoming beyond identity. For, in cramped space-without self-secure delineated identity-even the most personal, particular concern is infused with a wealth of social relations and forces. Politics thus ceases to be a self-referential process of self-actualization, and becomes a process of engagement with, and disruption or 'deterritorialization' of, the social relations that traverse minorities and determine their movements. For Deleuze and Guattari, drawing on Marx, the overall plane of minor political composition is the manifold of capitalist social relations, defined as the forces and constraints of production. As such, Deleuze and Guattari (1988: 472) propose that 'The power of minority, of particularity, finds its figure or its universal consciousness in the proletariat', where the proletariat is not a fully present class that 'faces' the bourgeoisie, but the totality of minor problematizations and inventions immanent to the capitalist socius (cf. Thoburn 2003). Cramped and missing as it is, the milieu of minor composition on this proletarian plane is never able to settle, or develop into an autonomous 'people' and a set of major authors. Instead, it is characterized by the 'incessant bustle' of minor authors, and is charged with vitality, with polemic, and with a continuous process of interrogation and invention that 'absorbs everyone no less than as a matter of life and death' (Kafka, cited in Deleuze and Guattari 1986: 17).

The wobblies, as I will show, were very much a 'missing' people who were propelled from their cramped experience of the social relations of work into considerable political and cultural invention. The aim of this article is not to present a comprehensive history of the IWW, but to understand its mechanics, its technical principles of composition; the article explores the IWW as a social machine for producing minor effects. This minor political approach necessitates an engagement with the consistency of the movement as a whole, encompassing both broad social relations of production and particular inventions, styles, cultural forms and political techniques. The article has two main parts. The first part is concerned with the IWW's mode of composition, and starts with the general plane of wobbly composition in work - that plane marked above as the 'proletariat'. It shows how the IWW's formation of the 'working class' functioned to produce not a major political identity or subject-either as a space of working-class autonomy or as one of social democratic rights and representation-but an inclusive plane of composition immanent to the cramped spaces of work across the social. I then show how the IWW's rather stripped-down focus on a politics of work served to politicize a wealth of social relations, and continuously problematize and ward-off a series of major identities, from the worker to the immigrant, the American, the citizen, and the 'people'. This part ends with a consideration of the relation between the 'rebel' and 'solidarity' as the technical core of wobbly political creation, or its minor author-function. With the general mode of wobbly class composition laid out, the second part of the article explores two aspects of wobbly minor political composition and invention in detail, in the hobo and the politics of sabotage. 


\section{The Inclusive Plane of Production}

When the IWW declared that it was an organization of the 'working class' it meant this, at one level, in the most simple and dualistic of senses. As is evident in the Preamble, the employing class and the working class composed two communities on either side of a cleavage derived from 'the essential point' (St. John, in Kornbluh 1998: 43) of production relations. This was the IWW's 'Declaration of Independence' (cf. Smith, in Kornbluh 1998: 113-20). Naive as it first might seem, this model was actually a rather pragmatic and modern approach to emerging Taylorist production (cf. Bologna 1972). Whereas craft unionism had been composed of numerous distinct groupings and craftsubdivisions, representing an 'aristocracy' of skilled labour (against, not least, women, black descendants of slaves, and recent immigrants), the IWW sought to bring all workers into 'One Big Union' appropriate to modern machine-intensive work. Here, following the classic Marxist framework, old craft identities were being subsumed into a mass proletariat, and work, as a distinct practice assembled around the rhythm of the labourer, was being subsumed in capital, now under the rhythm of the machine: "The worker, wholly separated from the land and the tools, with his skill of craftsmanship rendered useless, is sunk in the uniform mass of wage slaves' (IWW, in Kornbluh 1998: 7). ${ }^{3}$ In this context, the craft unions were seen by the IWW as reinforcing an old and redundant model of politics based on respect for particular subdivisions of work, and indeed for 'work' itself as a positive source of class identity. As a redundant form, craft unions were in consequence reactionary. Not only were they unable to fight capital on its modern terrain, they served to reinforce the identities, particular skills, subdivisions, and institutions of work necessary for the effective exploitation of labour, and as such were 'an instrument of capitalism' themselves (Industrial Union Bulletin 1907, cited in Ramirez 1978: 200). ${ }^{4}$

The 'working class', however demarcated from the bourgeoisie, was founded not, then, on a distinct social group, but on an understanding and experience of work across the social totality; it was a 'proletarian' composition immanent to and against the manifold productive relations of capital. Following this understanding of class, the membership criteria of the One Big Union was: 'None but actual wage workers shall be members ... No one shall be excluded from membership because of creed, color, or sex' (IWW 1972: 9). This 'race' and sex inclusivity was in itself groundbreaking, but, on the principle that organization should begin with the least skilled, ${ }^{5}$ the IWW also included itinerant labour (as I show below, this group had considerable significance), the unwaged, and precarious and illicit workers (it was the first American labour union to consider housework as work, and to organize chambermaids and prostitutes, and it is still unusual in this (Bird et al. 1987: 55-6)). Later constitutions thus continue: 'No unemployed or retired worker, no working class student, apprentice, or housewife, shall be excluded from membership on the grounds that he or she is not currently receiving wages' (IWW 1972: 9). ${ }^{6}$ For the IWW, it was through organizing a mass of differentially identified workers (around craft, 'race', sex, nationality, language), or, rather, against their differential identity, on a more generalized plane as 'fellow workers' that their collective response to the employers was to be effective. This is especially evident in the IWW's efforts toward the organization of black labour. As Foner (1976) has shown, the craft unions had frequently been not only exclusionary, but at the cutting edge of racist 
practice (racism and sexism being effective means of reinforcing craft identity). The railroad brotherhoods of the late nineteenth century were often more backward than even the judiciary and the mainstream Church in their exclusion of black workers not only from the unions, but from jobs themselves, and into the twentieth century they continued to express a most pernicious racism. ${ }^{7}$ The IWW on the other hand, even in the South, sought to organize black and white workers in the same unions. Essentially the point was always that working-class equality was the only means of preventing differential wages, strike breaking (a common AFL accusation against black workers), and racism. 'If you are a wage worker', an IWW leaflet addressed 'To Colored Workingmen and Women' declared, 'you are welcome in the IWW halls, no matter what your color. By this you may see that the IWW is not a white man's union, not a black man's union, not a red man's union, but a working man's union' (cited in Foner 1976: 110-11). Such a concern with the involvement of black workers also necessitated work on the prejudices of white workers. To give one example, a 1912 article in the Southern IWW paper Voice of the People by Phineas Eastman, entitled 'Down with Race Prejudice', asked that

fellow workers of the South, if they wish real good feelings to exist between the two races (and each is necessary to the other's success), to please stop calling the colored man 'Nigger'-the tone some use is an insult, much less the word. Call him Negro if you must refer to his race, but 'fellow worker' is the only form of salutation a rebel should use. (Cited in Foner 1976: 109)

\section{Cramped Politics and the Critique of Work}

If the 'working class' was the network of productive relations that overcame the particular identities of skill, 'race', and sex, and acted as the IWW's plane of composition, the point of political activity in this network was 'work'. The limited franchise meant that the IWW's constituency was largely excluded from conventional political participation. ${ }^{8}$ Thus, as Bologna (1972: 21) has argued, for the mass of the population the liberties of the bourgeois civil and political spheres had been reduced to a single 'freedom to work'. But, given this situation, the IWW did not seek to enter the political sphere-unlike the contemporary Second International it discounted both parliamentary politics and the vanguard party. Instead, after the split with De Leon in 1908, it concerned itself exclusively with 'economic' struggle at the point of production. ${ }^{9}$ This stripped-down focus on work served not, however, to limit political activity, but to open it to an engagement with the experiences and social relations that traversed the assorted minorities that made up the plane of the working class. Haywood makes the expansiveness of the focus on work very clear. 'The Industrial Workers of the World is not a political organization', he says, but this does not mean that it is not 'political'. Indeed,

industrial unionism is the broadest possible political interpretation of the working-class political power, because by organizing the workers industrially you at once enfranchise the women in the shops, you at once give the black men who are disenfranchised politically a voice in the operation of the industries; and the same would extend to every worker. (In Kornbluh 1998: 50; emphasis added)

If work was the focus, this did not, however, serve to produce a workerist identity- 
across the politicized plane of production the wobblies were to remain a 'cramped' and 'missing' people. As is clear in the Preamble, there was no identity founded on 'A fair day's wages for a fair day's work'. Work was a site of 'class war', a meeting point of two fundamentally opposed camps that allowed no in-between space of compromise and possible identity formation. But if work was a 'differend' ('a case of conflict, between (at least) two parties, that cannot be equitably resolved for lack of a rule of judgement applicable to both arguments' (Lyotard 1988: xi)), one party had the ability to define the terrain-workers had to work. ${ }^{10}$ The only route open for the wobblies, then, was to push a particular tendency in and against the regime of work in a fashion that warded-off any settling into identity in that regime. ${ }^{11}$ This tendency — towards the 'Abolition of the wage system'-was characteristically simple: 'Fewer hours, more wages and better conditions' (under the maxim: 'No terms with an employer are final' (Bruns 1980: 147)). With an antagonistic tendency rather than a 'fair demand', the wobblies were compelled to continuous agitation and invention of tactics as they propagandized for anything from the 8-hour day, to the 6-hour, even 4-hour day, 4-day week, and maintained a policy of refusing all labour contracts (since contracts were seen as means of producing and supporting differentials between workers and preventing solidarity action). ${ }^{12}$ 'Right and wrong', as one wobbly claimed (in an essay explaining why he took up a piece-rate job-something that the IWW discouraged), was 'a matter of gettin' results' (Winstead, in Kornbluh 1998: 283).

\section{Neither Immigrants nor Americans}

Just as the IWW's plane of class both engaged with and problematized work and the identity of worker, the IWW equally politicized, and refused to settle into the identities of immigrant, American, citizen, and people; in the midst of these identities they continued to be a missing people. Immigrant workers were a prime constituency for the IWW's conception of 'organizing from the bottom up', and their diversity of experience clearly added much to the IWW's pool of skill, political experience, and culture. An account of a 'free speech fight' in Aberdeen, Washington, in 1911 is illustrative of the IWW's immigrant composition. A series of wobblies take it in turns to stand on the soap-box and utter a few words before being arrested and taken away (the object of free speech fights was to swamp-to-bursting the courts and jails of towns where wobblies were prevented from street-corner speaking, and it became quite an art form $\left.{ }^{13}\right)$. Each one is differentiated by his national or cultural background, and concomitant dialect. After a 'Down East Yankee', 'descendent of the Pilgrims of the Mayflower',

came a short, swarthy German, evidently from the Schwartzwald. 'Mein Fellow Vorkers! Schust you listen by me vhile I tells you somethings!' But what that 'something' was he could not tell before he was seized and hustled in the wake of the other two. After the German came a large, raw-boned Irishman with the brogue of the ould sod thick on his tongue. 'Fellow Workers! Oi'm not much of a spaker, but Oi don't suppose Oi'll be allowed to talk long, anyhow.' That was all the speech he was allowed to make before he too was led away.

Next in line was an Italian who shouted the regular greeting of 'Fellow Workers', spoke a few rapid fire words and was taken towards the jail. From another part of the crowd a five-foot man 
with the unmistakable rolling gait of a sailor sprang to center of the cleared street, shouted 'Fellow Workers', and had time enough to make perhaps the longest 'speech' of the evening. 'I have been run out of this town five times by the Citizen's Club, and every time I have found my way back. This proves conclusively that the world is round.' (Payne, in Kornbluh 1998: 103)

The wobblies' ideas, practices and people seemed to exceed the nation-state- 'If you don't like it, then go back where you came from' was a familiar heckle to wobbly agitators (and, indeed, many were deported for political activity), and there was much talk of 'foreign' agitational ideas. But the wobblies themselves had a more complex relation to their immigrant status. Whilst they drew strength from, and expressed pleasure in, their complex cultural composition (as is clear in the phonetic transcription of the speeches above), they did not affirm a 'foreign' identity. As the soapboxer J. P. Thompson put it, 'there is no such thing as a foreigner. We are all native-born members of this planet' (in Kornbluh 1998: 316). ${ }^{14}$ But neither did the wobblies claim an 'American' identity; they suggested, rather, that they experienced little of being American, save the freedom of wage-labour. One cartoon by Joe Hill (in Kornbluh 1998: 129) interpreted the constitutional guarantee as 'Life?, Liberty? and the pursuit of - a Job!' with a migratory worker pursuing a fleeing nymph with 'Job' on her crown and holding a pork chop just out of reach (the veritable utopia of the pork chop is a persistent wobbly theme). A song, 'My Country', written by O. E. B. during the 1914-18 War, begins as a patriotic ode to the author's 'country', only to reveal later that 'My country is boundless/It has no limit/No king, no potentate-/Only a race of human beings.' The absence of this country is then marked: 'I do not dwell in my country,/But I can live in the hopes it holds/For the future' (in Kornbluh 1998: 329). Yet it was in America, amongst these eclectic immigrant peoples that the IWW emerged. The movement was not a collection of minorities and immigrants infusing in an American melting-pot, but something new that emerged from the particular conjunction of modern industrial capital, poverty and oppression, internal marginals, and European migrants across the American social plane. An anonymous article from 1922, entitled 'Why I am a Member of the I.W.W.', put it like this:

And lastly, although I am a foreigner, it is only because I am in America that I am an I.W.W. For, contrary to the belief of many, the I.W.W. is an outgrowth of advanced economic development in America, and the Italian, the Russian or the Swede that you may find in the organization here would not have been 'wobblies' had they remained in their native countries. (In Kornbluh 1998: 289)

\section{... nor Citizens or People}

I have already shown how the constituency of the wobblies-women, black descendants of slaves, immigrants, itinerant workers, youth-existed outside of the category of the citizen, and how the IWW made no attempt at 'political' enfranchisement. Instead, and concomitant with its politics of production, the IWW subjected the 'citizen' to considerable critique. The citizenry figure most frequently in wobbly literature as a self-satisfied molar majority that claims historical authenticity against the foreignness of labour radicals-'good Christian people' who, stars and stripes flying high above the cross, went 
to the new world to freely practise their religion, and force others to do the same (cf. Smith, in Kornbluh 1998: 115). A song to the executed anarchists Sacco and Vanzetti conveys this image of the American citizen well. An 'American' says:

But the hell of it is, they ain't got no-

Wotta ya call it?-

Oh yes, no historic past.

If they ever get one o'them they'll be all right.

Then they can talk about 1776

Instead of yellin' their fool heads off About Garrybaldeye an' Spartycuss.

But they're nothin' but God damn dagoes.

Now me: I'm an American, I am.

We're the real people, we are...

They not only don't know nothin' about books 'n' music,

' $\mathrm{N}$ ' inventin' ' $\mathrm{n}$ ' science,

'N' makin' purty pictures ' $n$ ' such things,

But they don't even know howta talk

The American language right. (Seymour, in Kornbluh 1998: 358)

The IWW also refused to align with the apparently popular democratic image of 'the people', as is made clear in Joe Hill's short piece, 'The People' (in Kornbluh 1998: 136-7). It begins with the opening line from 'The Red Flag'- 'The People's flag is deepest red'-and the question, 'who are the people?' Hill suggests that assorted bosses and governors have always been 'for the people', but that

When the Red Flag was flying in Lower California [the Tia Juana uprising] there were not any of 'the people' in the ranks of the rebels. Common working stiffs and cow-punchers were in the majority, with a little sprinkling of 'outlaws', whatever that is. (Hill, in Kornbluh 1998: 137)

'The people' simply came to gawk at 'The wild men with their Red Flag' before fleeing back to the 'Land of the Graft and the Home of the Slave'. The lesson for Hill was that

it is about time that every rebel wakes up to the fact that 'the people' and the working class have nothing in common. Let us sing after this 'The Workers' flag is deepest red' and to hell with 'the people'. (Hill, in Kornbluh 1998: 137)

\section{... but Rebels in Solidarity}

One is tempted to see a little of the romanticism of the outsider and the marginal in Joe Hill's figure of the rebel, but it is actually a rather complex figure that works against identity and as a principle of invention. The rebel breaks with the citizen and the people, but not in any splendid isolation. Hill mentions 'outlaws' with uncertainty ('whatever that is'), but rebels are part of - they operate in 'solidarity' with-a definite working class. One can think of the rebel/solidarity couplet as the principle of the IWW's creativity, and one that can be usefully considered in terms of Deleuze and Guattari's 
minor author-function. In the cramped space of minor peoples there is no room or means for the emergence and elevation of autonomous authors or actors, for 'an individuated enunciation that would belong to this or that "master" and that could be separated from a collective enunciation' (Deleuze and Guattari 1986: 17). Rather, the author and the collective are enmeshed within each other, such that each utterance 'takes on a collective value' (17). Creativity ceases to be the product of an author committing her particular autonomous experience to prose or action, but is rather a complex elaboration of a collective intrigue, a 'collective enunciation'. This is not to say that there is no space for innovation or singularity-far from it. The author is both of the milieu that $s /$ he actualizes 'collectively' and, in as much as the people are missing or lack coherence, is in a position to express a different configuration, a different sensibility unconstrained by a fixed identity (and relatively freed from the weight of tradition that would come with a coherent people). At the same time, because there is no space for the elevation of master authors ('whose great gifts could silence at least the majority of cavillers' (Kafka 1999: 142)), the author-function is distributed across the milieu. As such, invention and expression emerge not in distinct subjects, but at a multiplicity of 'borderlines' or 'anomalous' points - points of difference or minority within, or at the limits of the community that problematize particular experience, bring new relations into being, and lead the community into new territories (cf. Deleuze and Guattari 1988: 243-7).

The minor author-function of the rebel/solidarity couplet can be seen through some moments in wobbly composition. The 'collective value' of IWW composition is amply evident in the wobblies' opposition to conventional forms of leadership or authorship (a popular refrain was 'we are all leaders'), their cult of anonymity (such that cultural material was frequently produced anonymously or credited to IWW membership numbers or monikers, most commonly 'slim'), and their faith in the organization that at times takes on the importance, as Kafka describes minor composition, of 'a matter of life and death' (cf. Giovannitti, in Kornbluh 1998: 194)—and indeed, for their membership and activity, thousands were imprisoned, tortured, tarred and feathered, beaten, lynched or shot. One prisoner wrote:

We hardly thought of ourselves as individuals and gauged our actions by the value they would be to the defense, the organization and the working class. We did not feel this as those who profess religious conviction by some sort of sudden revelation, but by the association with one another and the realization that the group and the thing that the group stood for were far more important than the individual. (Jack Leonard, in Kornbluh 1998: 126)

This force of faith in the collectivity was not born of a fetishization of the organization, but was necessitated by the need for effective political action-sanctioned as it was in terms of 'solidarity'. As Pierce C. Wetter put it:

Solidarity — the basic, ineradicable, human faith that an injury to one is an injury to all-is the spirit, the very essence of our organization ... [T] o compromise the principle of solidarity is essentially disloyal not only to the rest of the group, but to the whole vital cause for which we stand. (In Kornbluh 1998: 348)

If a subsumption of the autonomous individual, this collective was not, however, a 
negation of singularity or creativity. In the IWW, singularity was a function not of the individual, but of 'the rebel'. The rebel is a marker of creativity, or 'action', but her authorial moment occurs only as part of the milieu, and, as such, rebel activity needs to be seen as a collective enunciation rather than a distinct subject-position. The creation comes not from the rebel's autonomous identity, but from pushing and developing an aspect of a politicized situation, be it in cultural production or tactic innovation and practice (in a strike, for example, 'individual' action, to be effective, is necessarily part of a collective). This is not to say that the wobblies did not have their prominent figures_-'Big' Bill Haywood, Elizabeth Gurley Flynn, Ben Fletcher, Joe Hill-but their import resides in their immanent relation to the collective. These people had particular styles or competencies that at times tipped the community into new configurations, but they did not 'lead' as such, and had no autonomous authorial role independent from the movement and the crowd of unnamed wobbly agitators.

For example, one can, interpret the proper name 'Joe Hill' in minor authorial terms, following the spread and use of his songs, cartoons, reputation, almost his myth, as they reverberated through the wobbly movement. Two moments from the story of Joe Hill's imprisonment and death (following a dubious conviction for murder) are illustrative. First, a Solidarity appeal for defence funds:

Now there is not one in this organization that can say he does not know this man. For wherever rebels meet, the name JOE HILL is known. Though we do not know him personally, what one among us can say he is not on speaking terms with 'Scissor Bill', 'Mr. Block' or who has not heard the 'White Slave' or listened to a rendering of the famous 'Casey Jones' song and many others in the little red song book? (In Kornbluh 1998: 129)

Second, his funeral rites. After his execution, and a large and long funeral ceremony with addresses in ten different languages, Hill was cremated. His wobbly badge, cuff-links and necktie were removed to be preserved at IWW headquarters and the coffin handles were detached to be melted down for a plate with the words of Hill's last letter engraved on it, 'Don't waste time mourning for me-organize' (cited in Kornbluh 1998: 155) The flowers were sent to IWW locals, and in a strange rite, his ashes were parcelled up and sent to locals around the world with instructions to scatter them to the winds on May Day 1916. So, in the Solidarity appeal, Hill's invention and influence is signalled via his songs as they in turn are linked to the obligatory marker of wobbly community, 'the little red song book', such that his singularity affirms and intensifies the collective value of solidarity. Then, every aspect of Hill's death and body - the most personal of events and spaces-is infused with collectivity as it is utilized for the composition of the movement. It is as if nothing can be wasted for the cause of 'organization', within which Hill's complexity and rebel creativity, rather than simple identity, are implicated. Perhaps expressing something of this role, shortly before his execution Joe Hill wrote, 'Tomorrow I expect to take a trip to the planet Mars and, if so, will immediately commence to organize the Mars canal workers into the I.W.W.' (in Kornbluh 1998: 127).

\section{The Hobo}

Having discussed the general mode of wobbly composition-as a class movement that 
operated in and against the plane of work, warded-off and undermined a series of major identities, and performed a minor author-function-I will now turn to consider the forms and creations of one particular group of workers prominent in the IWW, the hobos or itinerant workers. The hobos were simultaneously workers, outsiders, shirkers, and 'hobohemians', and it was through their anomalous positions, on the borderlines of these forms and relations, that their political and cultural invention occurred.

\section{Workers, outsiders and anti-work culture}

When a Department of Justice agent reported on the activities of the IWW hobos in California and Washington he said that the movement was composed 'chiefly of panhandlers, without homes, mostly foreigners, the discontented and unemployed, who are not anxious to work' (cited in Preston 1963: 60-1). This characterization is more than a little reminiscent of Marx's (1973: 197) description of the extra-social and politically conservative lumpenproletariat. However, the crucial point of the hobos' relation to the IWW was that they were workers, and as such were a prime constituency for Haywood's conception of 'organizing from the bottom up'. Essentially, the hobos were itinerant labourers who travelled the country for seasonal and temporary employment, particularly in logging and agriculture, but also in construction, manufacturing, mining, sheep shearing, fishing, ice harvesting, railroad laying, trench digging and so on. ${ }^{15}$ If the cowboy was born of the capitalization of cattle-rearing across the American plain (Beasts of Burden 1999), the hobo was the worker of the second frontier, 'a creature of the frontier' (Anderson 1975: ix) called forth by the railroad and the intensification of industry across the territory, and dissipating with the growth and consolidation of mining and manufacturing towns and the development of the automobile. As capital both required and made the hobo, then concomitant with his mobility was his selective and adaptive capacity: 'Adapting to the strange and new in tools, work, machines, and scenes was for him a normal consequence of moving.' (Anderson 1961: xiv) Thus, as one wobbly wrote:

The migratory workers were the most versatile body of men that ever developed on this continent. A tunnel had to dug, a bridge built, a dam constructed. The word went out and the workers with various skills would respond. The painters, riggers, mechanics, printers, teamsters-any trade you name would arrive at the job by boxcar. (Jack Miller, in Bird et al. 1987: 37)

At the same time, a certain model of the 'outsider' was prevalent in hobo culture. Though central to production, the itinerants continued to be represented as rather sorry, marginal and/or dangerous figures, ${ }^{16}$ and were frequently arrested as vagrants. The hobos themselves understood their outsider status in more nuanced terms. In wobbly songs and other literature there are frequent references to complete exclusion and poverty- 'It's not living, just saving funeral expenses' was a popular refrain. In one song, 'The Popular Wobbly' by T-Bone Slim (in IWW 1989: 37-8), a 'mild manner'd' wobbly experiences a whole host of oppressors from police, judge, jailer, to the bedbug and flea who 'go wild, simply wild' over him. Perhaps, he ponders, even the roses will do the same in his grave. Yet the hobos did not wallow in their exclusion; in many ways they affirmed it. They were indeed poor and oppressed, the most missing of people, but there is a clear verve 
and vibrancy in the culture, as is evident in one of the earliest wobbly songs, 'Hallelujah on the Bum'. As the refrain exemplifies, it is a song of typical grim humour that, as the author claimed, appealed to the 'jungle stiffs' with its 'rollicking, devil-may-care lilt': 'Hallelujah, I'm a bum,/Hallelujah, bum again,/Hallelujah, give us a handout-/To revive us again' (cited in Kornbluh 1998: 71). Recognizing something of this vibrancy, Jack London (1907) presented the hobo, if a little romantically, in terms of Nietzsche's overman. And, indeed, it is possible to see the hobos' mode of 'exclusion' as marking less an outsider identity, than a minoritarian 'willed poverty' that was functional to an overcoming of their structural positions and identities. Certainly, the IWW press appears to have seen it in these terms. An article in Solidarity in 1914 described their 'anomalous position, half industrial slave, half vagabond adventurer' thus:

The nomadic worker of the West embodies the very spirit of the I.W.W. His cheerful cynicism, his frank and outspoken contempt for most of the conventions of bourgeois society, including the more stringent conventions which masquerade under the name of morality, make him an admirable exemplar of the iconoclastic doctrine of revolutionary unionism. (Cited in Kornbluh 1998: 66-7)

Central to this anomalous overcoming was the hobo's attitude to work. If the hobo existed immanently to the regimes of production, work was not a popular pastime. In most accounts, tales, and songs of the hobo, one finds him upping and leaving work rather readily; if going to another job, it is distant jobs that are popular (rather than local, if better paid ones) (Anderson 1961: 5). In one wobbly/hobo autobiography, Henry McGuckin (1987: 11) recounts his first lesson in hobo ethics. Amongst other things, including a pragmatic judgement on theft based on the relative likelihood of capture, his hobo friend conveys that 'Work was something to be done only as a last resort. As long as you could eat and sleep warm without it, leave it alone.' 'King' Dan O'Brien similarly suggests that a dislike of work was prevalent: '[The hobo] swears that when work becomes an art and a joy, he will take off his coat and go to work' (cited in Feied 1964: 17-18). And in 'The Hobo's Last Lament' the last words of a dying hobo are for 'No tears' because he is going to a land 'Where beef-stews grow on bushes ... Where they hate the word called work' (in Anderson 1961: 212). Other accounts have hobos desperate for non-existent jobs and rejecting the notion that they are bums, but in the IWW conception of the working class - a proletarian formation, in and against work - these two positions are not mutually exclusive. ${ }^{17}$ It is perhaps best to see the anti-work ethic operating as a propulsive force away from each job, and, in terms of 'class war', within and against work, in conjunction with the attractor of the wage to each new job.

\section{Jungle culture, hobohemia and dromomania}

From this general mode of composition the hobos developed a complex existence. The nodal points of hobo life between work were the hobo 'jungles', or camps, and 'hobohemia'. Jungles were usually situated near railway junctions and skirted the edges of towns, close enough to enable hobos to 'bum lumps' (ask for handouts), and find or steal food, but not so close as to attract attention. Life in the jungles seems to have been organized through both a strong personal anonymity - as is reflected in one photograph 
of a strangely empty camp that Anderson (1961: 10) captions, 'A jungle camp-the "bos" hid from the camera'-and a considerable degree of organization that Harry Kemp describes as a 'marvel of cooperation' (cited in Kornbluh 1998: 67; cf. Anderson 1961: 21-5)

If the jungles were the temporary camps, Chicago's 'hobohemia' was a nodal point for longer stay. Chicago (the largest railroad centre), or 'Big Chi', was the hobo Mecca: 'For the 'boes all roads, it seemed, led to Chicago' (Bruns 1980: 162). According to Anderson's (1961) territorial-social map, hobohemia was an isolated part of Chicago, subdivided in four parts, all known as the 'main stem', and comprised 'flop houses', cheap meal houses, and saloons. ${ }^{18}$ Here 'swarm[ed]' a 'polyglot population' of bootleggers, dope peddlers, professional gamblers, 'jack rollers', drunks, 'lady barbers', 'bathing beauties', vagabond poets, non-hobo workers seeking a cosmopolitan night out, bohemians, and so on (Anderson 1961: 5-9). Anderson's account is particularly interesting for its keen sense of the dynamism of hobohemia. This dynamism had multiple causes, but was most essentially linked to hobohemia's function as a centre for hobo workers. It is not just that, because of this, more money circulated here than in East-coast slum districts, but that also a cosmopolitanism was brought in through the hobos' continuous circulation. Hobohemia was functional both to capital (as a labour exchange, or 'slave market'), and to the consolidation and multiplication of hobo styles. As well as having bookshops (such as 'The Hobo' and 'The Proletariat', the latter also provided mail collection and storage services for hobos) and from 1915, the IWW headquarters (enabled largely by the membership dues of migratory workers (Bruns 1980: 157)), hobohemia was where the hobo arts of 'getting by' and 'killing time' were honed and spread. Soapbox speaking was a constant activity. Though Anderson (1961: 219-20) describes the speeches as like a game with a limited number of pieces and a limited number of moves' (there was certainly a continual repetition of themes and expressions such as 'One Big Union', 'an injury to one is an injury to all', and 'solidarity forever'), the wealth of styles, tricks and subjects (economics, biology, psychology, sociology, class war, free love) that he details (216-29), as well as their popularity, make it clear that there was considerable difference in the repetition.

The trajectories between the jungles and hobohemia were defined by railroads under the impetus of possible jobs, radical actions, or changing seasons. Hobos would move around the country by riding the 'rattlers' (freight trains), inside or on the 'rods' (draw-rods beneath the freight carriages), by 'flipping' (boarding a moving train) on the outskirts of towns. Though the hobos would sometimes be helped by railroad workers, mostly it was a difficult and dangerous practice since they were up against not only railroad police, but also hijackers who would extract money or throw them off the train, so 'greasing the rails' (cf. Murphy, in Bird et al. 1987: 46). According to Parker (1920: 121), between 1901 and 1905 nearly 23,964 trespassers (mostly tramps and hobos) were killed on the railroads, and over 25,236 were injured. Nevertheless, freight riding was the only means of movement, and the IWW made efforts to prevent the hijacking with 'flying squads', who, in some cases, cut and scarred 'IWW' on hijackers' faces. Though freight riding was often presented as a necessity to be avoided, it was, at the same time, frequently affirmed in terms of 'wanderlust' and 'dromomania'19 — as with much of hobo culture, the hobos' relation to freight riding was complex, and offered no easy site for uncomplicated identity formation. One wobbly described 'riding the rails' as a way of 
experiencing the 'grandeur and beauty' of the West, suggesting that 'That's the feeling we all had. I think that's one of the reasons we kept on moving' (Archie Green, in Kornbluh 1998: 71). Another 19 year old 'does not know why he travels except that he gets a thrill out of it ... He has tried [to settle down] a few times but the monotony of it made him so restless' (Anderson 1961: 83). But Ben Reitman, the 'hobo surgeon' and sometime lover of Emma Goldman, perhaps best expressed the ambiguity of the hobos' relation to freight riding by comically self-pathologizing his love of movement as a 'neuropathic craziness, a fugue, “ambulatory automatism", (Bruns 1980: 171). As Bruns (1980: 171) put it, 'It was his hobby, his sport, and his disease.'

\section{Getting by, hobo slang and hieroglyphics}

As Anderson (1961) details, hobos had a wealth of means, techniques, grafts for 'getting-by' and 'killing time' whilst on the road, themselves often described ironically as 'work'. Central to these was the composition and performance of tales and songs. Hobo songs ${ }^{20}$ and tales usually give practical and political information. In 'The Flight into California', for example, a biblical parody advocates industrial sabotage:

Chapter $13 \ldots$

(2) Where dwelleth one called Bill which is surnamed Scissor, and seeing him sore afflicted with patriotic leprosy we administered unto him much Industrial Unionism.

(3) Saying unto him, Go thou into the harvest and work for a dollar,

(4) And when the harvest is ripe and thy lord needeth thee sorely

(5) Strike for two dollars, saying unto thy lord:

(6) Behold, thy fruit goeth unto the devil, pay us two dollars or great shall be the destruction thereof ... (Metcalf, in Kornbluh 1998: 75)

Integral to the arts of getting by, and manifesting a minor deterritorialization of language (cf. Deleuze and Guattari 1988: 102-5), was a certain hobo slang. Irwin's (1931) glossary of hobo slang, compiled over 20 years of hoboing, extends to some 180 pages. It includes such terms as 'angel food'-mission preaching, 'cat'-itinerant worker, on the fringe of hobo and 'yegg' (criminal) groups, 'carrying the banner'-walking the streets all night to avoid being arrested as a vagrant or to keep warm, 'hep'-well-informed, 'pearl diver'-dishwasher, 'snipe shooting' - picking cigarette stubs from the street. The language was in continual flux, and extensive use of a term would lead to variation in meaning, subdivision, and further invention of terms (Anderson 1961: 99). Irwin (1931: $14,12)$ thus suggests that hobo vernacular 'changes imperceptibly from week to week' and can be 'but poorly understood in all its ramifications except by those in constant touch with it'. Though it featured at most only marginally, the hobos also developed a form of hieroglyphics. Symbols would be left at assorted sites of note by passing hobos to indicate such things as places good for handouts (a cross on a gate, or parallel lines on a station), hostile towns (two semicircles with dots for eyes), and restaurants that offered food in exchange for dish washing (a plate with knife and fork) (for illustrations see Anderson 1961: 15; Bruns 1980: 32; Kornbluh 1998: 86). 


\section{Hobo/wobblies}

The IWW made considerable effort at organizing hobos, and though recruitment was initially very slow, after their involvement in the Wheatland Hop Fields Riot in 1913 (cf. Parker 1920: 169-99) membership increased dramatically. Whilst even at its high point only a minority of hobos were in the IWW, it was by far the most popular of hobo organizations (cf. Anderson 1961: chapter 16). However, for two main reasons it is best not to think of the hobo/IWW relation simply in terms of membership numbers. First, the relation between the organization and hobo culture was less one of identity than feedback. Whilst wobbly rebel activity added new dimensions to the hobo way of life, many IWW practices were formed through the structural, ethical, and cultural experiences and practices of the hobo. Indeed, Anderson (1961: 230-1) suggests that "[The IWW] was conceived on the "stem", and cradled and nurtured by the floating workers'. A few examples can illustrate. One of the most successful wobbly unions, the Agricultural Workers Organization, invented a system of recruitment - the 'job delegate system'-based on migratory practices. Essentially, a group of mobile organizers would start in the early spring at the Mexican border, and end in late Autumn in the Canadian provinces, recruiting new members, collecting dues, selling literature, passing on news and tactics, and organizing industrial action as they went. As Georgakas (in Bird et al. 1987: 8) describes the arrangement, 'A local could exist in the hat or satchel of a mobile delegate.' In the specific case of industrial action, Anderson (1961: 234) describes how the more skilled mobile agitators would operate a three-wave strategy: the first 'official agitator' would arrive at a workplace and merely 'fan the flames of discontent', making no attempt at organization, the second, 'pioneer organizer', started the work of forming a local before being dismissed, and the third, 'real organizer', would work more subtly and quietly at detailed organization, often only becoming known to the employer once demands were made. The mainstay wobbly practices and arts of street-corner preaching and song also originated with the hobos, and were first seen in the IWW when J. H. Walsh organized a travelling wobbly band, the 'Overalls Brigade', which, dressed in black shirts, denim overalls, and red kerchiefs, toured the Northwest, parodying Salvation Army hymns and popular songs to attract workers to street-corner meetings. The songs were printed on pocket-sized cards and sold for 10 cents. Around 1909 this was expanded to become the first wobbly 'little red song book'.

Second, though there are reports of wobblies effectively forcing membership on hobos (the IWW red card enabling them to enter certain jungles and ride certain trains- though this was frowned upon officially), and there is no doubt that membership dues were important to the organization, wobbly membership was rather loose and fluctuating, related to particular events and situations. Hobos might join during periods or sites of radical action, and let dues and involvement wane at other times (indeed, dues tended not to accumulate, but emerged as momentary strike funds). Thus, although it had many permanent core militants, the IWW as a mass movement was less a fixed body than a series of intense 'swells' from the plane of the working class, where individuals may or may not have always called themselves wobblies, or have maintained continuous membership. Parker (1961: 115) thus writes:

In the history of American labor there has appeared no organization so subject to fluctuation in 
membership and strength. Several times it seemed on the point of joining the Knights of Labor in the graveyard of labor class movements, but energized by some strike flare it appears again as an active force.

This sense of a 'swell', and rather anonymous, even mysterious movement was clearly evident in popular perception. One senator, for example, lamented:

you cannot destroy the organization ... It is something you cannot get at. You cannot reach it. You do not know where it is. It is not in writing. It is not in anything else. It is a simple understanding between men, and they act upon it without any evidence of existence whatever. (Cited in Kornbluh 1998: 255)

\section{Sabotage}

If IWW engagement with the differend of work was marked by a principle of continuous agitation that prevented a falling-back into the identity of work, the wobblies' central political tactic was 'sabotage'. Conventional wisdom is that the word derives from the act of French workers throwing their sabots (wooden clogs) into the works of the machine. This is, however, a little inaccurate. Emile Pouget, who first introduced the term to the syndicalist movement at the 1897 Toulouse conference of the General Confederation of Labour (CGT), traces the word to the expression 'de travail exécuté "comme à coups de sabots"'- 'to work clumsily as if by sabot blows', or 'as if wearing sabots' (Pouget 1977: 3; 1913: 37). This in turn derived from a Scottish practice of 'go cannie', or 'go slow'. ${ }^{21}$ The term first appeared in wobbly literature in Solidarity (4 June 1910) in the context of strike solidarity. Between 1914 and 1918 it was directly advocated by the IWW, but the practice extends before and after these dates in less formal ways-it seems as though the IWW ceased advocating sabotage for fear of prosecution. The signs of sabotage-the black cat and the sabot-crop up throughout wobbly literature, songs, cartoons, and 'silent agitator' stickers in varied fashion. It thus needs to be defined in terms of its technical principles.

\section{Beyond the strike}

Sabotage is best understood as an intensification of the strike; a manifestation of its sense-its intended effects - rather than its timeless structure. 'Of all things revolutionary, so far', Pouget's report to the CGT on boycott and sabotage stated, 'we have as yet found and applied only the strike-and it is the strike alone that we continually resort to' (1913: 49). The strike was an old technique; Linebaugh and Rediker (1990: 240) date its origin as far back as 1768 , when sailors in London ports collectively 'struck' down ships' sails to bring commerce to a halt. What is more, seen in the context of craft unionism, the strike had a divisive function. The ebb and flow of craft union workers striking, returning to work, accepting union-management resolution, and signing different contracts with non-interference clauses was such that the strike became part of the production of craft identity in and around work, not part of the overcoming of work. The strike could also be somewhat destructive of radical energies. Trautmann, for 
example, describes how 'a tremendous epidemic of strikes a few years ago, conflicts expressive of a general discontent finding its outlet in vehement eruptions', ended 'only with a pitiful exhaustion of vitality' (in Kornbluh 1998: 18).

Against the tendency of the strike to bolster craft identity, sabotage was more suited to the IWW's conception of the differend of work. Rather than a luddism, or outright destruction-and following Gurley Flynn's (1993) definition of sabotage as 'the conscious withdrawal of the worker's efficiency'-sabotage was almost always presented as a flexible and innovative, delicate and skilful engagement with the particularities of work (cf. Pouget 1913: 32-3), as part of the IWW's continuous agitation for 'fewer hours, more wages and better conditions'. For example, Joe Hill suggested that

Striking on the job is a science and should be taught as such. It is extremely interesting on account of its many possibilities. It develops mental keenness and inventive genius in the working class and is the only known antidote for the infamous 'Taylor System'. (In Kornbluh 1998: 142-3)

There are countless testimonies to the effectiveness of this tactic which enabled workers to continue drawing pay, prevent lay-offs and direct confrontations with the police (who were not averse to using guns against strikers), maintain anonymity, and yet cause considerable upset for the employers-so encouraging them to meet the workers' demands. Joe Hill thus advised:

The best way to strike ... is to 'strike on the job'. First present your demands to the boss. If he should refuse to grant them, don't walk out and give the scabs a chance to take your places. No, just go back to work as though nothing had happened and try the new method of warfare. (In Kornbluh 1998: 142)

\section{Anonymity and proliferating characteristics}

A number of characteristics arise from this initial premise. First of all, sabotage was anonymous. Rather than an heroic, identity-forming walk-out, sabotage was carefully and selectively taken up by IWW rebels across the plane of work, whilst remaining unnamed and unidentified..$^{22}$ As such, it expressed the minor authorial composition of the movement, multiplying its effects and intensity without any individualization of authorship. In his rather romantic turn of phrase, Pouget $(1913: 36,73)$ writes that sabotage 'is present everywhere and everywhere invincible': 'There can be no injunction against it. No policeman's club. No rifle diet. No prison bars. It cannot be starved into submission. It cannot be discharged. It cannot be blacklisted.' It is 'worse than a pestiferous epidemic'. The black cat itself was already 'an old symbol for malignant and sinister purposes, foul deeds, bad luck, and witchcraft' (Green, cited in Kornbluh 1998: 59), and, making use of this popular conception, the wobblies frequently described it as a rather mystical and anonymous, even abstract, force. One poem suggests, for example, that 'They'd better not throw “wobs" in jail/And leave the kitten free' (in Kornbluh 1998: 61). That sabotage was a tactic of an unidentified collectivity is further marked by the fact that it appears that no wobbly was ever prosecuted for the practice.

As well as being anonymous, sabotage also offered the potential for a proliferation of styles. Since the particulars are determined by individual conditions and knowledges, 
Pouget (1913: 101) argues that the possible forms are as infinite as 'an endless rosary'. The complexity of the practice can be exemplified with one of numerous sabotage variants, 'following the book of rules'. It is clear that the time needed to comply with safety rules and regulations is not compatible with the timetable of production. Yet if an accident occurs, 'the book of rules' enables the individualization of responsibility to a particular employee rather than the employer (or the production process itself). Deliberate and responsible attention to the rule book thus operates as a break on production, utilizing instituted regulations against that particular work regime (cf. Gurley Flynn 1993: 20-2). In another example, Pouget (1913: 99) recounts how a group of striking fur factory workers reduced the size of the garment patterns by a third so that all orders completed whilst they were on strike would be wasted (and the patterns could easily be readjusted once they returned). Gurley Flynn (1993) even includes workers' family planning as at one with the spirit of sabotage ('reducing the supply of producers'), and, indeed, as Tax (1980) shows, a class-based reproductive and sexual politics was a central aspect of feminist wobbly activity, at a time when more mainstream feminism shunned such embodied matters in favour of the suffrage question.

\section{Conclusion}

Summoning the wretched of the earth to call forth the new world, the version of 'The Internationale' sung by the IWW proclaims, 'We have been naught, we shall be all' (IWW 1989: 6). This article has explored the nature of this 'naught'. I have argued that in the midst of the social relations of work and the identities of craft union politics, the immigrant, the American and the people, the wobblies composed a simultaneously diffuse and cramped 'working class'. The plane of class served to form relations across the minority identities of women, hobos, black descendants of slaves, and immigrants that was functional to the overcoming of work and its identities, whilst at the same time it operated on the condition that 'the people are missing' in a certain 'willed poverty' that warded-off identity and compelled a continuous agitation and invention. Each minority experience and concern - be that of itinerant ways of life, the experience of racism, or the problem of reproductive control-marked a particular site of political and cultural intervention and creation. But, cramped and interlaced with social relations, each site of composition was to be developed only through forming relations with other minorities in the class, as part of the agitation for 'Fewer hours, more wages and better conditions' and toward the 'Abolition of the wage system'. As the hobo, in his strange amalgam of the worker and the outsider, was presented as an exemplary case of minor composition immanent to the IWW's conception of class, sabotage was shown to be the driving force of the continuous struggle and invention in and against work.

To conclude by returning to the broader theoretical argument of this article, the IWW has been shown to present a rather different model of class from that of orthodox Marxism and the dominant narratives of new social movement theory. Rather than a coherent and unified social group, the IWW's formation of class resided in processes of political composition, where, as Deleuze and Guattari (1983: 255) put it, the question of the working class 'belongs first of all to praxis'. Whether or not in contemporary societies, as Pakulski (1995: 76) argues, 'class divisions are waning and the political 
relevance of class in general is declining', I hope to have shown that we would be wrong to see contemporary new social movements as the sole constituency for a politics of difference and variation-or, indeed, to see 'class issues', to cite Pakulski again, as tied to coherent economic concerns and unable to manifest a lightness and diversity. Indeed, the wobblies might encourage us to consider how class politics and engagement with the relations of production can operate in a more culturally inventive, minority-attuned, and politically challenging fashion than those that over-readily bracket-off the question of capital.

\section{Acknowledgements}

I am grateful to Nikolas Rose for his comments on an early version of this article, to Margot Butler, Ben Gidley, Runa Khalique and Martha Michailidou for discussion about the issues raised, to Charles H. Kerr Publishing Company for permission to cite from Kornbluh (1998), and to Tim Jordan and the anonymous referees of this article for their comments.

\section{Notes}

1 This is the full text of the 1908 Preamble, still in use today. It includes some important amendments to the 1905 version, following the split with Daniel De Leon over his advocacy of 'political' (electoral) struggle.

2 As I have argued elsewhere, and against orthodox Marxism, this is the essence of Marx's understanding of the proletariat, where, as Gilles Dauve (1997: 31) has put it, 'The proletariat is not the working class'-as a substantial social identity - 'rather the class of the critique of work' and its identities (cf. Thoburn 2002).

3 For further discussion of Marx's understanding of the 'real subsumption' of labour in capital see Thoburn (2001).

4 Exemplifying this point, Ramirez (1978: 196) cites some contemporary employers' expression of fear that a gap in representation by the craft AFL could be filled by the IWW. The advocate of collective bargaining, Ralph Easley, wrote that 'If the [steel-workers] are not organized by the American Federation of Labor, an organization standing for American Institutions, they will sooner or later be organized by the Industrial Workers of the World.' Gertrude Beeks similarly argued that 'the AF of L is the greatest fighting force in the country against Socialism and the IWW's'.

5 Haywood made this point at the founding congress:

I do not mean that this organization is going to improve the condition of purely skilled workers, but I mean we are going to get at the mass of the workers and bring them up to a decent plane of living. I do not care a snap of my fingers whether or not the skilled workers join this industrial movement at the present time. When we get the unorganized and the unskilled laborer into this organization the skilled worker will of necessity come here for his own protection. As strange as it may seem to you, the skilled worker today is exploiting the labor beneath him, the unskilled man, just as much as the capitalist is. (Cited in Ramirez 1978: 200)

6 This account should be seen as marking a distinction between the IWW and other movements, and showing, at the least, its political intentions, not as suggesting that all social prejudice was overcome. Tax (1980) provides a critical analysis of the place of women in the IWW, showing both its progressive and reactionary aspects with much fascinating detail of the forms of organization developed by IWW women, their relation to the wider feminist movement, and their conflicts with some of the more reactionary male wobblies. As well as organizing radical activity amongst women, Tax argues that the IWW's most important contributions here were in linking the workplace and the community, and integrating the demand for (and much 
practice of) reproductive freedom with the general class struggle. Tax locates the problematic aspects of the IWW's gender politics around their 'economism'. This is a not unsurprising target (since economistic workerism has historically been so effective in marginalizing women), but, as my argument should make clear, I think in this case it is an inadequate basis for critique, since it was through the IWW's emphasis on class that so much innovation and broad appeal occurred. This inadequacy is actually evident implicitly in Tax's work itself. These two sentences, for example, jar: 'This economism ... was a severe weakness in the IWW's work. Despite it, the IWW was able to reach out in an extraordinarily sensitive way to women' (127).

7 An example can convey the extremes of racism in this milieu. In 1910 the assistant grand chief of the Brotherhood of Locomotive Engineers explained why they abandoned attempts to organize in Cuba in these terms:

we were unable to distinguish the nigger from the white man. Our color perception was not sensitive enough to draw a line. I do not believe the condition will improve in a year from now or in 10 years from now or in any other time, unless you stock the island of Cuba with a new race, entirely getting rid of the old. ... I hope the time will never come when this organization will have to join hands with the negro or a man with a fractional part of a negro in him. (Cited in Foner 1976: 107)

8 As Georgakas (in Bird et al. 1987: 5) writes:

All women, all the many workers under twenty-one, and all unnaturalized foreign-born workers-the vast majority of working America-were legally disenfranchised. In those parts of the United States where black labor was dominant, procedural harassment and outright intimidation kept most blacks from voting. Other large blocks of workers-seamen, itinerants, and lumberjacks-were unable to maintain registration at fixed polling sites.

9 This led to an early split with Bolshevism. Though the IWW was initially very excited by the Soviet revolution and was the Third International's initial focus for an American Communist Party (Draper 1957: 150, 242-3), by 1920 Lenin (1965: 46) condemned the IWW along with the left-communists for their 'infantile' refusal to work within orthodox unions and the parliamentary system. An editor's footnote to the Beijing edition of 'Left-Wing' Communism (Lenin 1965: 130-1) describes the IWW thus:

Its activities were marked by pronounced anarcho-syndicalist traits: it did not recognize the necessity of political struggle by the proletariat, denied the leading role of the proletarian party, the need for an armed uprising to overthrow capitalism and the struggle for the dictatorship of the proletariat. The I.W.W. refused to work in the American Federation of Labour unions and subsequently degenerated into a sectarian anarcho-syndicalist group exerting no influence whatsoever on the workers.

10 Lyotard (1988: $\$ 12)$ presents the differend of work thus:

contracts and agreements between economic partners do not prevent—on the contrary, they presupposethat the laborer or his or her representative has had to and will have to speak of his or her work as though it were the temporary cession of a commodity, the 'service' which he or she putatively owns. This ... is required by the idiom in which the litigation is regulated ('bourgeois' social and economic law).

11 The centrality of the critique of work was such that, alongside Marx, Paul Lafargue's anti-work polemic, The Right to be Lazy, was essential wobbly reading.

12 The wobbly song 'The Big Strike' put the case thus: 'Why do you make agreements that divide you when you fight/And let the bosses bluff you with the contract's "sacred right"?/Why stay at work when other crafts are battling with the foe;/You all must stick together, don't you know?' (cited in Kornbluh 1998: 36).

13 An example provided by Kornbluh (1998: 71) is typical of the style:

Another soapboxer, an outdoor lecturer in the Spokane area, had been a circuit preacher in the South. Dressed as an old Southern colonel in a longtailed black coat and a soft-brimmed black hat, he would drawl softly: 'This is my text tonight, Fellow Workers. It's about the three stars. They're not the stars of Bethlehem. They're better than the stars of Bethlehem. The stars of Bethlehem lead only to Heaven which nobody knows about. These are the three I.W.W. stars of education, organization, and emancipation. They lead to porkchops which everybody wants.' 
14 As it enacts a conversation between a 'foreign man' and a 'scissorbill' (non-class-conscious worker), Dublin Dan's song 'Dan McGann' presents a keen critique of the category of 'foreigner'. Dan McGann says: 'Don't talk to me of the bourgeoisie,/Don't open your lips to speak/Of the socialist or the anarchist,/Don't mention the Bolshevik/I've heard enough of your foreign stuff.' The reply at once brings home the idiocy of working-class nationalism, and the always already hybrid nature of 'national' culture: 'The "foreign" man looked at Dan McGann,/And in perfect English, said:/"I cannot see, for the life of me, /What you have got in your head./You boast and brag 'bout the grand old flag/And the foes you put to rout, /When you haven't a pot in which to spit,/Or a window to throw it out./You howl and kick about the bolshevik, /The anarchist and Wob-/You defend this rotten system when/you don't even own your own job." ... "You're working for an Englishman,/You room with a French Canuck,/You board in a Swedish restaurant/Where a dutchman cooks your chuck;/You buy your clothes from a German Jew,/Your shoes from a Russian Pole,/And you place your hope in a dago pope,/To save your Irish soul”, (in Kornbluh 1998: 30-2).

15 Though the numbers of hobo women were, until the 1930s, relatively small, there were women hobos in this period. Whether hoboing through wanderlust, political activity, or sexual and lifestyle freedom against the domestic norm, women hobos' work tended to be based in towns. See Ben Reitman's (2002) fictional 'autobiography' of a 'sister of the road' for insight into the experience of women hobos, and Weiner (1984).

16 For example, Carlton Parker and Rexford Tugwell, respectively, suggest that the hobo was 'stamped by the lowest, most miserable labor conditions and outlook which American industrialism produces' and was 'a rather pathetic figure ... wracked with strange diseases and tortured by unrealised dreams that haunt his soul' (cited in Kornbluh 1998: 66). Parker (1920) presents a kind of materialist Freudian reading of the IWW as a 'psychological by-product of the neglected childhood of industrial America' (100), where 'inferiority phobia' (46) induces 'sublimation activities' (49) and aggressive 'inferiority compensation' (51), most notably as inferior work, wanderlust, sabotage, and the strike. See also Speek (1917).

17 Even when hobos self-identified as bums, it was usually only in comparison to the capitalists as the 'real' bums. One tale, called 'The Two Bums' (in Milburn 1930: 120-1), presents both hobos and capitalists as bums, only the former is 'lighter' and his condition is caused by the latter. One verse runs: 'The bum on the rods is a load so light/That his weight we scarcely feel,/But it takes the labor of dozens of men/To furnish the other a meal.'

18 Each area had a particular constituency: 'West Madison'- 'slave market' of employment agencies, and home of the more down and out and petty criminal, 'Bum Park'-a place for sleeping and paper reading, 'Crumb Hill'- the same, but with more drunks, 'Bughouse Square'-the 'Latin Quarter' of hobohemia, where bohemia and hobohemia merged. Anderson's account is extensive indeed; no doubt 'the most far-reaching examination of Hobohemia ever undertaken' (Bruns 1980: 183). Anderson himself had an immigrant and hobo background and lived in hobohemia whilst doing his research (cf. Anderson 1975). The research itself was inspired by a meeting with the 'hobo surgeon' Ben Reitman, and written whilst a graduate student in Sociology at the University of Chicago. In the context of the empiricism of the Chicago School it is interesting that Anderson describes his research as not the kind of 'participant observation' where one would 'descend into the pit, assume a role there, and later ascend to brush off the dust' (Anderson 1961: xiii). Rather, it was immanent to his exit, a way of 'getting by' (and he deliberately uses the hobo term) on his way out. Perhaps not unrelated to these conditions of production, whilst the text at times insists on the paucity of hobo culture, through the great detail of its account of, and intimacy with, the hobo, it also clearly affirms something of the experience. This is in strong contrast to Carlton Parker's (1920) only slightly earlier research that, whilst it claims intimacy with its object against a 'detached academic' observation, actually mobilizes a most transcendent and determinist theoretical framework to capture the IWW as an always already foreclosed and tragic 'finished product' (96) of an immature society.

19 The deserter in the ancien régime was known as a 'dromomaniac', and psychiatry has since applied the term to compulsive walkers (cf. Virilio 1986: 153). Whilst dominant culture sought to pathologize this aspect of hobo culture (cf. Lewis 1907), the hobos tended to affirm it as something of a countercultural 'revolutionary wandering' (to use Virilio's (1986: 5) expression).

20 Hobo and wobbly songs, never an autonomous art form, were immanent to the life of the hobo and rebel. They were composed by many, usually unnamed, authors, were often directed to particular political ends and ways of getting by, frequently parodied dominant cultural norms, and were most commonly sung to the tunes of popular songs and hymns such as 'John Brown's Body', 'America', and 'Onward Christian Soldiers' (cf. IWW 1989; Milburn 1930). 
21 Fred Thompson (in Kornbluh 1998: 37) offers a slightly different inflection, suggesting that 'saboteur' was a general term applied to peasants (still wearing wooden shoes when industrial workers were wearing leather) who were frequently used as strike breakers. On return to work the workers would mimic the clumsy work of the saboteur. In this vein, Gurley Flynn (1993: 11) cites a circular sent to Scottish dockers after they had lost a strike in 1889 :

The employers like the scabs, they have always praised their work, they have said how much superior they were to us, they have paid them twice as much as they ever paid us: now let us go back on the docks determined that since those are the kind of workers they like and that is the kind of work they endorse we will do the same thing. We will let the kegs of wine go over the docks as the scabs did. We will do the work just as clumsily, as slowly, as destructively, as the scabs did. And we will see how long our employers can stand that kind of work.

22 In Red Harvest Dashiell Hammett (1982: 12) presents a subtle take on wobbly awareness of the difference between effective tactics and heroic identity. Here, an IWW organizer's advice to use sabotage rather than go on all-out strike is disregarded for not being 'active enough'. When, as the wobbly foresaw, the strike is used to break the movement, he says, disparagingly, they 'wanted to put themselves on the map, make labor history'.

\section{References}

Anderson, N. (1961) [1923] The Hobo: The Sociology of the Homeless Man, Chicago: University of Chicago Press/Phoenix.

Anderson, N. (1975) The American Hobo: An Autobiography, Leiden: E. J. Brill.

Balibar, E. (1991) 'From Class Struggle to Classless Struggle?', in E. Balibar and I. Wallerstein Race, Nation, Class: Ambiguous Identities, London: Verso.

Beasts of Burden: Capitalism-Animals-Communism (1999) London: Antagonism Press.

Bird, S., Georgakas, D. and Shaffer, D. (1987) Solidarity Forever: The IWW-An Oral History of the Wobblies, London: Lawrence \& Wishart.

Bologna, S. (1972) 'Class Composition and Theory of the Party', trans. B. Ramirez, Telos, 13: 4-27.

Bruns, R.A. (1980) Knights of the Road: A Hobo History, New York: Methuen.

Conlin, J. R. (1969) Bread and Roses Too: Studies of the Wobblies, Westport, CT: Greenwood.

Dauvé, G. (1997) 'Capitalism and Communism', in G. Dauvé and F. Martin The Eclipse and Re-emergence of the Communist Movement, revised edition, London: Antagonism Press.

Deleuze, G. (1989) Cinema 2: The Time-image, trans. H. Tomlinson and R. Galeta, London: Athlone.

Deleuze, G. (1995) Negotiations 1972-1990, trans. M. Joughin, New York: Columbia University Press.

Deleuze, G. and Guattari, F. (1983) Anti-Oedipus: Capitalism and Schizophrenia Volume 1, trans. R. Hurley, M. Seem and H. R. Lane, London: Athlone.

Deleuze, G. and Guattari, F. (1986) Kafka: Toward a Minor Literature, trans. D. Polan, London: University of Minnesota Press.

Deleuze, G. and Guattari, F. (1988) A Thousand Plateaus: Capitalism and Schizophrenia Volume 2, London: Athlone.

Draper, T. (1957) The Roots of American Communism, New York: Viking.

Feied, F. (1964) No Pie in the Sky: The Hobo as American Cultural Hero in the Works of Jack London, John Dos Passos, and Jack Kerouac, New York: Citadel.

Foner, P. S. (1976) Organized Labor and the Black Worker 1619-1973, New York: International.

Gurley Flynn, E. (1993) [1915] Sabotage: The Conscious Withdrawal of the Worker's Efficiency, London: Pentagon b Press.

Hammett, D. (1982) The Four Great Novels, London: Picador.

Industrial Workers of the World (IWW) (1972) Preamble and Constitution of the Industrial Workers of the World, Ithaca, NY: Glad Day Press.

Industrial Workers of the World (IWW) (1989) [1923] I.W.W. Songs to Fan the Flames of Discontent, facsimile reprint of the 19th edition, Chicago: Charles H. Kerr.

Irwin, G. (1931) American Tramp and Underworld Slang, London: Scholartis Press. 
Kafka, F. (1999) The Diaries of Franz Kafka, 1910-23, ed. M. Brod, London: Vintage.

Kornbluh, J. L. (ed.) (1998) Rebel Voices: An IWW Anthology, Chicago: Charles H. Kerr. [This is a 447-page A4 anthology edited by a member of the IWW.]

Lenin, V. I. (1965) 'Left-wing' Communism, An Infantile Disorder, Beijing: Foreign Languages Press.

Lewis, O. F. (1907) 'The Vagrant and the Railroad', North American Review, 185: 603-13.

Linebaugh, P. and Rediker, M. (1990) 'The Many-headed Hydra: Sailors, Slaves, and the Atlantic Working Class in the Eighteenth Century', Journal of Historical Sociology, 3(3): 225-52.

London, J. (1907) 'Hoboes that Pass in the Night', Cosmopolitan, 44: 190-7.

Lyotard, J.-F. (1988) The Differend: Phrases in Dispute, trans. G. Van Den Abbeele, Manchester: Manchester University Press.

Marx, K. (1973) Surveys from Exile, trans. B. Fowkes, ed. D. Fernbach, Harmondsworth: Penguin.

Marx, K. (1976) Capital: A Critical Analysis of Capitalist Production, Vol. 1, trans. B. Fowkes, Harmondsworth: Penguin.

McGuckin, H. E. (1987) Memoirs of a Wobbly, Chicago: Charles H. Kerr.

Milburn, G. (ed.) (1930) The Hobo’s Hornbook: A Repertory for a Gutter Jongleur, New York: Ives Washburn. Pakulski, J. (1993) 'The Dying of Class or Marxist Class Theory?', International Sociology, 8(3): 279-92.

Pakulski, J. (1995) 'Social Movements and Class: The Decline of the Marxist Paradigm', in L. Maheu (ed.) Social Movements and Social Classes: The Future of Collective Action, London: Sage.

Parker, C. H. (1920) The Casual Laborer and Other Essays, New York: Harcourt, Brace \& Howe.

Pouget, E. (1913) Sabotage, trans. A. M. Giovannitti, Chicago: Charles H. Kerr.

Pouget, E. (1977) Le Sabotage, Editions La Cheville Ouvrière.

Preston, W. (1963) Aliens and Dissenters: Federal Suppression of Radicals 1903-1933, Cambridge, MA: Harvard University Press.

Ramirez, B. (1978) When Workers Fight: The Politics of Industrial Relations in the Progressive Era, 1898-1916, London: Greenwood.

Reitman, B. (2002) [1937] Sister of the Road: The Autobiography of Boxcar Bertha, London: AK Press/Nabat.

Speek, P. A. (1917) 'The Psychology of Floating Workers', Annals of the American Academy of Political and Social Science, 69: 72-8.

Tax, M. (1980) The Rising of the Women: Feminist Solidarity and Class Conflict, 1880-1917, London: Monthly Review.

The Wobblies (1979) directed and produced by S. Bird and D. Shaffer, New York: First-run Features.

Thoburn, N. (2001) 'Autonomous Production? On Negri's “New Synthesis”, Theory, Culture \& Society, 18(5): 75-96.

Thoburn, N. (2002) 'Difference in Marx: The Lumpenproletariat and the Proletarian Unnamable', Economy and Society, 31(3): 434-60.

Thoburn, N. (2003) Deleuze, Marx and Politics, London: Routledge.

Urry, J. (1995) 'Rethinking Class', in L. Maheu (ed.) Social Movements and Social Classes: The Future of Collective Action, London: Sage.

Virilio, P. (1986) Speed and Politics: An Essay on Dromology, trans. M. Polizzotti, New York: Semiotext(e).

Weiner, L. (1984) 'Sisters of the Road: Women Transients and Tramps', in E. H. Monkkonen (ed.) Walking to Work: Tramps in America, 1790-1935, London: University of Nebraska Press.

\section{The Author}

Nicholas Thoburn teaches in the Department of Sociology at Goldsmiths College, University of London. He is the author of Deleuze, Marx and Politics (Routledge 2003). 